\title{
ANALISIS PERUBAHAN DAERAH POTENSI IKAN MENGGUNAKAN CITRA SATELIT MODIS LEVEL 1B (Studi Kasus : Selat Bali)
}

\author{
Bangun Muljo Sukojo ${ }^{1}$, Latifatul Zahroh ${ }^{1}$ \\ ${ }^{1}$ Departemen Teknik Geomatika, FTSLK-ITS, Kampus ITS Sukolilo, Surabaya, 60111, Indonesia \\ e-mail: ${ }^{1}$ bangun_ms@geodesy.its.ac.id
}

\begin{abstract}
Abstrak
Selat Bali merupakan perairan yang terletak diantara Pulau Jawa dan Pulau Bali yang merupakan daerah potensial untuk bidang perikanan. Karena letaknya yang dipengaruhi oleh Laut Jawa dan Samudera Hindia ini menyebabkan perairan di selat Bali mengandung banyak nutrien yang merupakan sumber makanan bagi ikan. Untuk mengoptimalkan potensi tersebut diterapkan teknologi penginderaan jauh yaitu pembuatan peta daerah potensi ikan. Pada penelitian ini daerah potensi ikan diidentifikasi berdasarkan beberapa parameter diantaranya konsentrasi klorofil-a yang berkisar antara $0.2 \mathrm{mg} / \mathrm{L}$ sampai $1 \mathrm{mg} / \mathrm{L}$, suhu permukaan laut antara $20^{\circ} \mathrm{C}$ sampai $30^{\circ} \mathrm{C}$ dan memiliki front thermal lebih dari sama dengan $0,5^{\circ} \mathrm{C}$. Parameter-parameter tersebut didapatkan dari pengolahan data dari citra satelit MODIS. Pengolahan konsentrasi klorofil-a menggunakan algoritma OC3M, sedangkan Suhu Permukaan Laut (SPL) menggunakan algoritma Minnet (2001). Hasil overlay dari kedua parameter tersebut kemudian digunakan untuk mengidentifikasi front thermal berdasarkan jaring ikan (fishnet) yang dibuat dengan ukuran $4 \mathrm{~km} \times 4 \mathrm{~km}$. Hasil dari penelitian ini menunjukkan bahwa daerah potensi ikan terbanyak terjadi pada bulan April 2012 yaitu sebanyak 45 daerah potensi ikan. Namun terjadi penurunan signifikan pada bulan Oktober 2012 karena hanya terdapat satu daerah potensi ikan. Sedangkan pada bulan Mei 2013 daerah potensi ikan meningkat kembali menjadi 22 daerah potensi ikan. Hal ini menunjukkan bahwa pada bulan April dan Mei daerah tersebut memiliki potensi untuk penangkapan ikan yang lebih banyak dibandingkan pada bulan Oktober.
\end{abstract}

Kata Kunci: Daerah Potensi Ikan, klorofil-a, MODIS, suhu permukaan laut

\begin{abstract}
Bali Stait is a fishery potential strait which located between Java and Bali Island. Bali Strait has much nutriens, which the nutrients are source of food for fish, because the influence of Java Sea and Indian Ocean. Remote sensing technology is used to make maps of fishery potential areas to optimalize the fishery potential of Bali Strait. On this research, fishery potential area is identified by some parameters. The parameters are $0.2 \mathrm{mg} / \mathrm{L}-1 \mathrm{mg} / \mathrm{L}$ concentration of chlorophyll-a, $20^{\circ} \mathrm{C}-30^{\circ} \mathrm{C}$ sea surface temperature and having $\geq 0.5^{\circ} \mathrm{C}$ front thermal. The parameters are obtained from data processing of MODIS satellite imagery. OC3M algoritm is used to process concentration of chlorophyll-a meanwhile sea surface temperature (SPL) is precessed by Minnet algoritm (2001). The overlay results of both parameters are used to identify front thermal based on $4 \mathrm{~km} \times 4 \mathrm{~km}$ sized fishing net (fishnet). The results of the research indicate that the greatest number of fishery potential areas are happened on April 2012 which the numbers are about 45 fishery potential areas. Significant decreasing of fishery potential areas is happened on October 2012 with only one remaining area of fishery potential. On May 2013 fishery potential areas increase to 22 areas. The results show that Bali strait has more fishery potential areas on April and May than October.
\end{abstract}

Keywords: Chlorophyll-a, MODIS, Fishery Potential Area, Sea Surface Temperature

\section{PENDAHULUAN}

Indonesia merupakan Negara maritim dan kepulauan terbesar di dunia karena memiliki luas laut dan jumlah pulau yang besar. Dengan luas wilayah laut 5,4 juta $\mathrm{km}^{2}$ mendominasi luas teritorial seluruh Indonesia sebesar 7,1 juta $\mathrm{km}^{2}$. Potensi tersebut menempatkan Indonesia sebagai Negara yang memiliki sumber daya kelautan yang besar. Proyeksi nilai kelautan Indonesia mencapai 171 miliar dollar AS atau setara dengan 2046 triliun Rupiah (kurs Rp. 12.000 per Dollar AS) yang meliputi perikanan (380 Triliun Rupiah), Wilayah pesisir (670 Triliun Rupiah) Bioteknologi (480 Triliun Rupiah) Wisata Bahari (24 Triliun Rupiah), Minyak Bumi (252 Triliun Rupiah) 
dan Transportasi Laut (240 Triliun Rupiah) (Pratama 2014).

Selat Bali merupakan perairan yang relatif sempit (sekitar 960 mil atau $1776 \mathrm{~km}$ ) menghubungkan Laut Flores dan Selat Madura di Utara dan Samudera Hindia di bagian selatan. Mulut bagian utara sekitar satu mil dan merupakan perairan yang dangkal (kedalaman sekitar 50 meter), sedangkan di bagian selatan memiliki wilayah yang luas yaitu sekitar $28 \mathrm{mil}(51,8 \mathrm{~km})$, merupakan perairan yang dalam. Letak geografis Selat Bali tersebut yang menyebabkan perairan selat bali terdapat banyak nutrien sumber makanan dari ikan (Wyrtki, 1961 dalam Arianto, Subiyanto dan Hani'ah 2014 ).

Teknologi penginderaan jauh atau remote sensing saat ini telah dapat melakukan penglihatan pada cakupan wilayah yang luas tanpa menyentuh benda tersebut dan dilakukan dengan waktu yang relatif singkat. Teknologi ini dapat digunakan untuk menentukan posisi daerah potensi ikan dengan mengidentifikasi beberapa indikator tingkat kesuburan perairan dan kelimpahan makan bagi ikan. Beberapa parameter yang sering dijadikan indikator tersebut adalah sebaran klorofil-a dan suhu permukaan laut. Suhu permukaan laut dan konsentrasi klorofil-a dapat diestimasi dengan teknik penginderaan jauh, dimana saat ini akurasi estimasi konsentrasi klorofil-a dengan menggunakan algoritma global untuk perairan lepas pantai adalah $70 \%$, sedangkan untuk SPL lebih tinggi tingkat akurasinya (Indrayani, Mallawa dan Zainuddin 2012).

Salah satu instrumen yang dapat digunakan untuk mendeteksi keberadaan klorofil dan suhu permukaan laut yaitu citra satelit MODIS. Citra MODIS dipilih karena memiliki luasan sapuan mencapai $2330 \mathrm{~km}$ dengan resolusi temporal 1 hari, sehingga data yang ada lebih beragam dan lebih mudah dilakukan pemilihan kawasan yang bebas awan. Citra satelit MODIS memiliki resolusi spasial yang beragam sesuai dengan levelnya yaitu $250 \mathrm{~m}, 500 \mathrm{~m}$ dan $1 \mathrm{~km}$. Namun yang sering digunakan dalam penelitian di daerah perairan adalah citra satelit MODIS level 1B karena sudah menerapkan hasil kalibrasi sensor dan geolocation yang ada pada level $1 \mathrm{~A}$ dan penerapan berbagai macam algoritma masih dapat dilakukan.

Untuk mendapatkan konsentrasi klorofil-a dan suhu permukaan laut dilakukan dengan algoritma dari kombinasi band yang ada pada citra satelit MODIS. Pada algoritma konsentrasi klorofil-a menggunakan algorithma OC3M (OCW 2010 dalam Semedi dan Safitri 2015) yang merupakan algoritma klorofil-a untuk daerah laut lepas. Algoritma tersebut menggunakan rasio dari nilai reflektan band 9 dengan band 12 . Kedua band tersebut berada pada kanal yang biasanya digunakan ocean color, mendeteksi fitoplankton dan biogeokima Sedangkan pada algoritma suhu permukaan laut menggunakan algoritma Minnet (2001) dalam Suwargana dan Arief (2004). Algoritma suhu permukaan laut tersebut menggunakan nilai kecerahan suhu dari band 3132. Kedua band tersebut berada pada kanal termal dengan resolusi spasial $1 \mathrm{~km}$.

\section{METODOLOGI PENELITIAN}

Lokasi penelitian ini terletak di Selat Bali yaitu pada koordinat adalah $8^{0} 24^{\prime} 0^{\prime \prime}$ LS sampai $8^{\circ} 54^{\prime} 0^{\prime \prime}$ LS dan $114^{0} 30^{\prime} 0^{\prime \prime}$ BT sampai $115^{\circ} 12^{\prime} 0^{\prime \prime}$ BT.

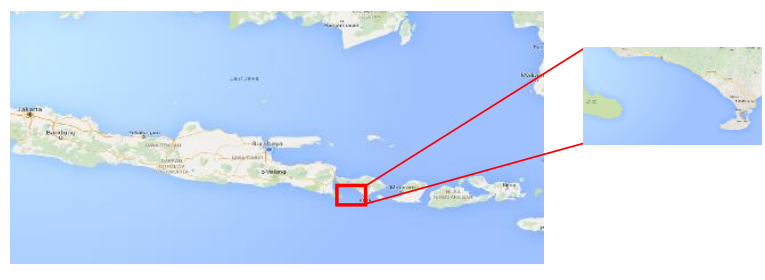

Gambar 1. Lokasi Penelitian

(Sumber: Google Maps, 2015)

Citra satelit MODIS yang telah didapat dari website http://ladsweb.nascom.nasa.gov/ kemudian digeoreference untuk memberikan sistem proyeksi pada citra sekaligus memasukkan data geolocation yang dimiliki citra satelit MODIS. Untuk memastikan bahwa proses tersebut sudah sesuai dilakukan perhitungan Strength of Figure (SOF) dan Root Mean Square Error (RMSE). Selanjutnya dilakukan konversi Reflectance Sun Band ke Reflectance pada band 9 dan band 12 yang akan digunakan untuk pemrosesan algoritma OC3M (Semedi \& Safitri, 2015) dan konversi Emmisive ke Brightness Temperature pada band 31 dan 32 yang akan digunakan untuk pemrosesan algoritma Minnet, 2001 (Suwargana \& Arief, 2004). Untuk membedakan antara daratan dan perairan digunakan algoritma Normalized Different Water 
Index (NDWI) dengan menggunakan rumus sebagai berikut:

$N D W I=\frac{(\text { Band4-Band2] }}{(\text { Band44+Band2] }}$

Suatu daerah dikatakan sebagai perairan jika nilai NDWI lebih dari 0 . Sedangkan untuk menghilangkan data pada daerah yang tertutup awan dilakukan cloud masking (Xiao 2004 ; Arafah, Sukojo dan Jaelani 2015) dengan rumus sebagai berikut:

$(\operatorname{Ref3} \geq 0,2) * 0+(\operatorname{Ref} 3 \leq 0,2) * 1$

Algoritma OC3M yang digunakan pada penelitian ini adalah sebagai berikut:

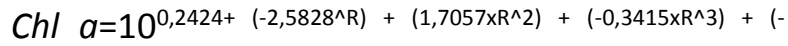
$\left.0,8818 \times R^{\wedge} 4\right)$

Dimana $\mathrm{Chl} a$ adalah konsentrasi klorofil-a (mg/L), $\mathrm{R}$ menyatakan logaritma dari perbandingan antara nilai reflektan band 9 dengan reflektan band 12. Sedangkan algoritma Minnet (2001) yang digunakan pada penelitian ini adalah sebagai berikut:

$S P L=-0,0024+3,53 \mathrm{~Tb}_{31}-2,52 \mathrm{~Tb}_{32}-0,582-273$

Dimana $S P L$ adalah suhu permukaan laut $\left({ }^{\circ} \mathrm{C}\right)$, $\mathrm{Tb}_{31}$ dan $\mathrm{Tb}_{32}$ menyatakan nilai Brightness Temperature dari band 31 dan band 32 . Kemudian hasil dari penerapan kedua algoritma tersebut dilakukan klasifikasi untuk mendapatkan daerah potensi ikan dengan nilai konsentrasi klorofil-a berkisar antara $0.2 \mathrm{mg} / \mathrm{L}$ sampai $1 \mathrm{mg} / \mathrm{L}$ sebagai batasan kesuburan perairan tropis (Septiawan 2006). Sedangkan SPL berkisar antara $20^{\circ} \mathrm{C}$ sampai $30^{\circ} \mathrm{C}$ merupakan suhu optimum bagi perkembangan fitoplankton di perairan (Effendi 2003). Daerah yang memenuhi kedua syarat tersebut kemudian dioverlay dengan jaring ikan (fishnet) yang berukuran $4 \mathrm{~km} \times 4 \mathrm{~km}$. Suatu fishnet dikatakan sebagai daerah potensi ikan jika terdapat front thermal lebih dari sama dengan $0,5^{\circ} \mathrm{C}$ pada lebih dari $50 \%$ dari luas area fishnet (Jatisworo dan Murdimanto 2013).

Untuk memvalidasi keakuratan dari daerah potensi ikan yang telah didapatkan, dilakukan uji korelasi data citra hasil penerapan algoritma OC3M (Semedi \& Safitri, 2015) dan algoritma Minnet (2001) (Suwargana \& Arief, 2004) dengan data insitu. Kemudian didapatkan Peta Daerah Potensi Ikan yang selanjutkan dianalisa untuk mendapatkan perubahan yang terjadi pada bulan April, Oktober 2012 dan Mei 2013.

\section{HASIL DAN PEMBAHASAN}

1. Perbaikan Citra

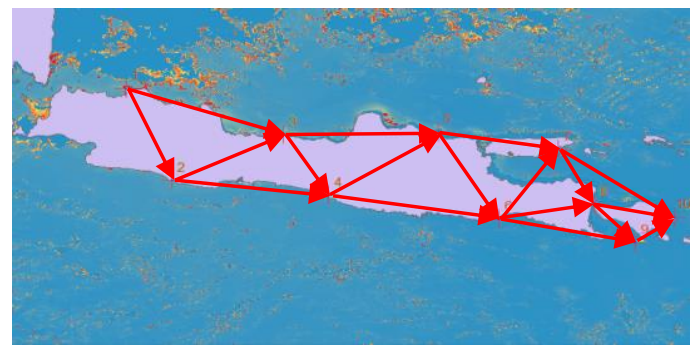

Gambar 2. Persebaran Titik Sampel Koordinat

Berdasarkan Gambar 2 didapatkan nilai SoF yang mendekati 0 yaitu sebesar 0,0012 . Hal tersebut menunjukan desain jaring tersebut memiliki kekuatan jaring yang bagus. Sedangkan nilai RMSE yang terlihat pada Tabel 1 menunjukkan nilai yang bagus karena memiliki nilai kurang dari 1 piksel dan mendekati 0 .

Tabel 1. Nilai Kesalahan RMS/RMSError

\begin{tabular}{llc}
\hline No & Tanggal & RMSE (Piksel) \\
\hline 1 & April 2012 & 0.748 \\
2 & Oktober 2012 & 0.225 \\
3 & Mei 2013 & 0.416 \\
\hline
\end{tabular}

2. Persebaran Klorofil-a dan Suhu Permukaan Laut Terklasifikasi

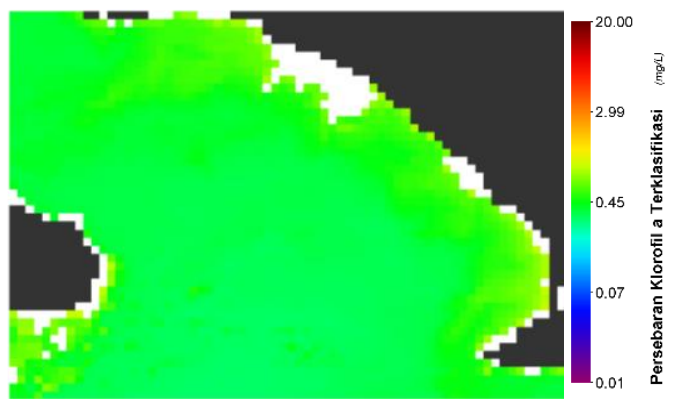

Gambar 3. Peta Persebaran Klorofil-a Terklasifikasi April 2012 


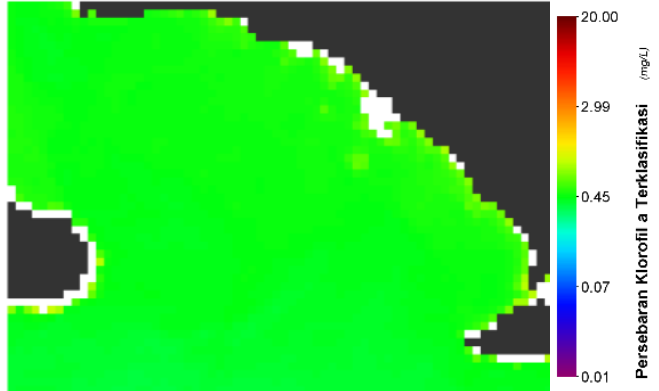

Gambar 4. Peta Persebaran Klorofil-a Terklasifikasi Oktober 2012

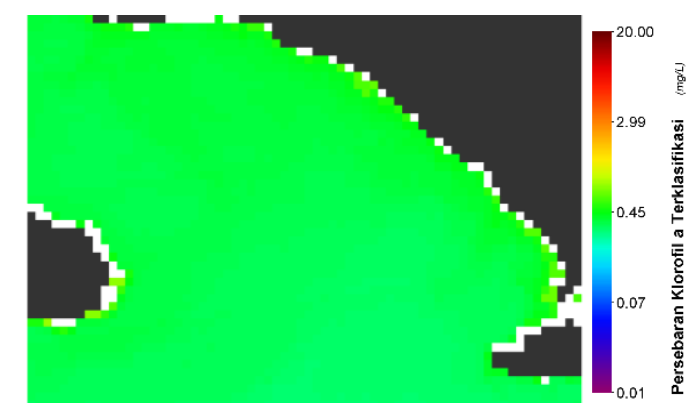

Gambar 5. Peta Persebaran Klorofil-a Terklasifikasi Mei 2013

Berdasarkan hasil klasifikasi nilai klorofil-a didapatkan persebaran klorofil-a seperti yang terlihat pada Gambar 3, 4 dan 5. Persebaran klorofil-a yang hampir merata menandakan bahwa perairan di selat Bali merupakan perairan tropis yang subur. Konsentrasi klorofil-a pada bulan April 2012 tetap memiliki interval paling panjang meskipun sudah dilakukan klasifikasi dengan gradasi warna yang lebih beragam dibandingkan dua bulan lainnya. Adapun nilai minimum dam maksimum dari klorofil-a yang telah terklasifikasi dijelaskan pada Tabel 2.

Tabel 2. Nilai Minimum dan Maksimum Klorofil-a Terklasifikasi

\begin{tabular}{lll}
\hline Tanggal & \multicolumn{1}{c}{$\begin{array}{c}\text { Nilai Minimum } \\
(\mathrm{mg} / \mathrm{L})\end{array}$} & $\begin{array}{c}\text { Nilai Maksimum } \\
(\mathrm{mg} / \mathrm{L})\end{array}$ \\
\hline April 2012 & 0,3194 & 0,9705 \\
Oktober & 0,3751 & 0,9818 \\
2012 & & \\
Mei 2013 & 0,3130 & 0,8057 \\
\hline
\end{tabular}

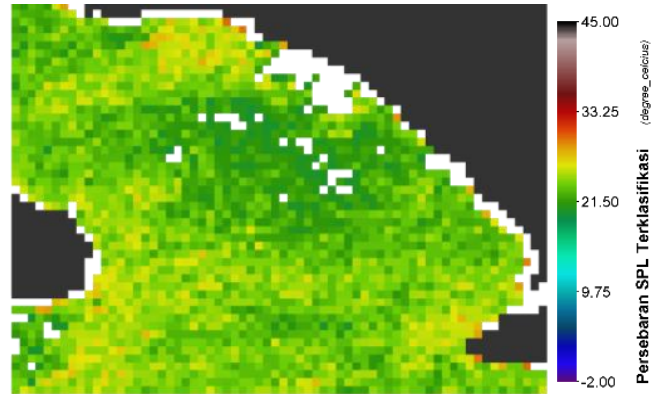

Gambar 6. Peta Persebaran SPL Terklasifikasi April 2012

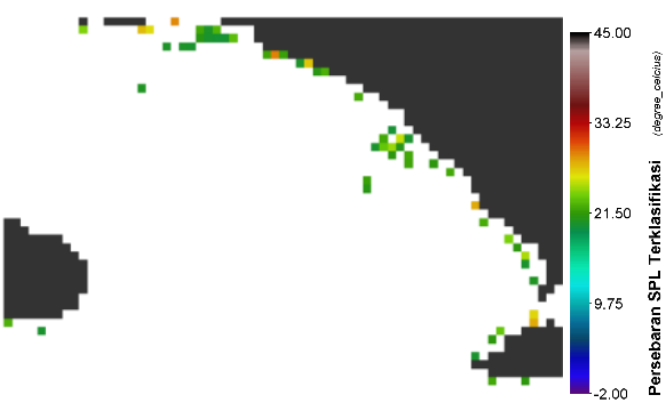

Gambar 7. Peta Persebaran SPL Terklasifikasi Oktober 2012

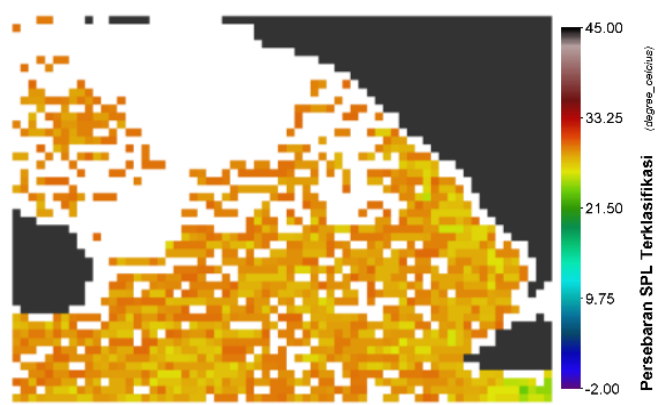

Gambar 8. Peta Persebaran SPL Terklasifikasi Mei 2013

Berdasarkan hasil klasifikasi SPL didapatkan persebaran SPL seperti yang terlihat pada Gambar 12, 13 dan 14. Persebaran SPL pada bulan April 2012 cenderung merata, sedangkan pada bulan Oktober yang memiliki SPL yang cenderung rendah hanya memiliki sedikit daerah persebaran SPL yang terklasifikasi. Hal tersebut terjadi akibat adanya periode monsun Australia, wilayah bumi bagian selatan lebih dingin dibandingkan dengan bumi bagian utara. Matahari saat itu berada di bumi bagian utara sehingga atmosfernya cenderung lebih hangat, hal ini diikuti oleh menghangatnya SPL di bumi bagian utara (Habibie \& Nuraini, 2014). Adapun interval dari nilai minimum dan maksimum SPL terklasifikasi seperti dapat dilihat pada Tabel 3. 
Tabel 3. Nilai Minimum dan Maksimum SPL Terklasifikasi

\begin{tabular}{lll}
\hline Tanggal & $\begin{array}{l}\text { Nilai Minimum } \\
\left({ }^{\circ} \mathrm{C}\right)\end{array}$ & $\begin{array}{l}\text { Nilai Maksimum } \\
\left({ }^{\circ} \mathrm{C}\right)\end{array}$ \\
\hline April 2012 & 20,0017 & 29.9366 \\
Oktober 2012 & 20,0597 & 29.3418 \\
Mei 2013 & 23,671 & 29.9996 \\
\hline
\end{tabular}

3. Peta Daerah Potensi Ikan

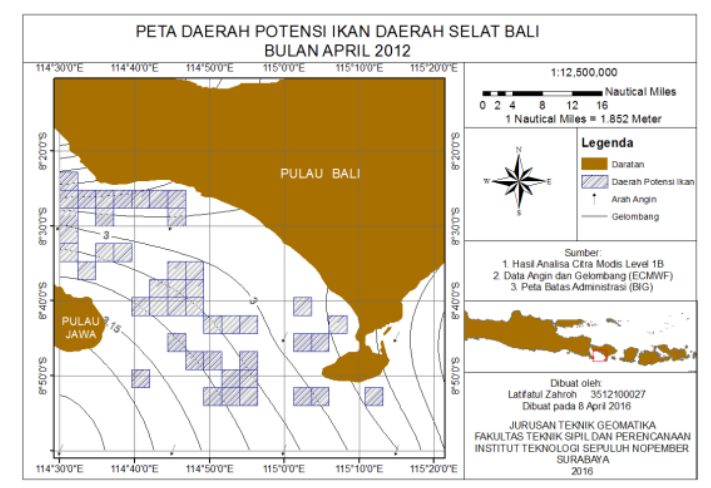

Gambar 9. Peta Daerah Potensi Ikan April 2012

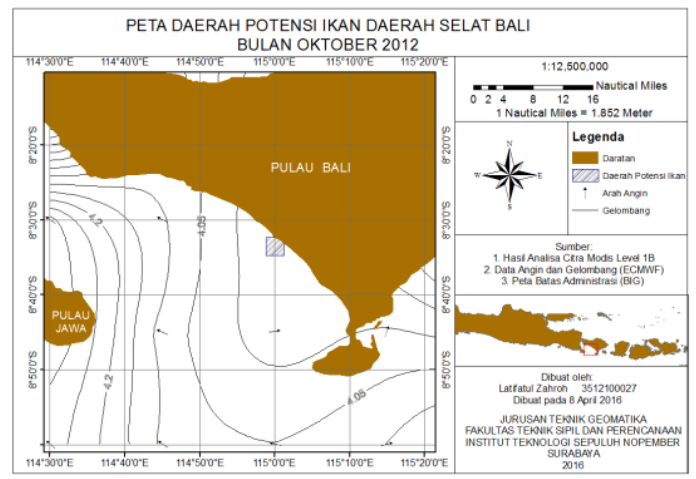

Gambar 10. Peta Daerah Potensi Ikan Oktober 2012

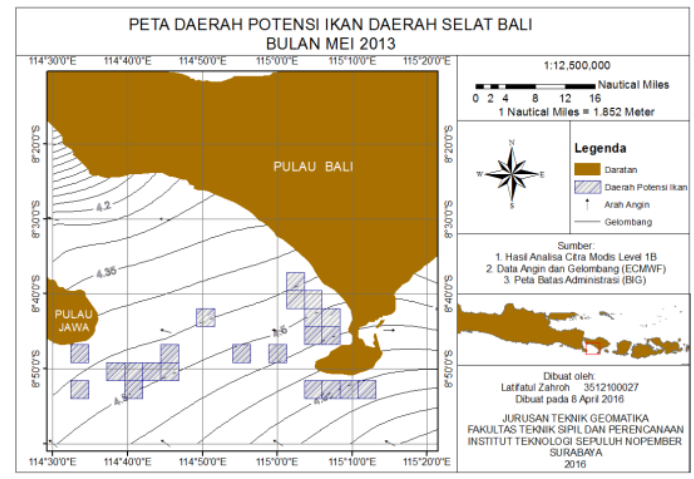

Gambar 11. Peta Daerah Potensi Ikan Mei 2013

Berdasarkan hasil klasifikasi klorofil-a dan identifikasi front thermal pada SPL didapatkan daerah potensi ikan sepeti terlihat pada Gambar 9, 10 dan 11. Pada Gambar 9 terlihat bahwa pada bulan April
2012 daerah selat Bali memiliki daerah potensi ikan yang sangat banyak yaitu 45 daerah potensi ikan. Sedangkan pada Gambar 10 terlihat bahwa bulan oktober 2012 jumlah daerah potensi ikan menurun menjadi satu daerah potensi ikan. Namun pada Gambar 11 terlihat bahwa bulan Mei 2013 jumlah daerah potensi ikan meningkat kembali meskipun tidak sebanyak pada bulan April 2012. Adapun koordinat dari masing-masing daerah potensi ikan dapat adalah sebagai berikut:

Tabel 4. Koordinat Daerah Potensi Ikan

\begin{tabular}{cccc}
\hline No & Tanggal & Lintang & Bujur \\
\hline 1. & April 2012 & $8^{0} 23^{\prime} 52,8^{\prime \prime}$ & $114^{0} 31^{\prime} 8,4^{\prime \prime}$ \\
2. & & $8^{0} 26^{\prime} 24^{\prime \prime}$ & $114^{0} 31^{\prime} 8,4^{\prime \prime}$ \\
3. & & $8^{0} 28^{\prime} 48^{\prime \prime}$ & $114^{0} 31^{\prime} 8,4^{\prime \prime}$ \\
4. & & $8^{0} 31^{\prime} 4,8^{\prime \prime}$ & $114^{0} 31^{\prime} 8,4^{\prime \prime}$ \\
5. & & $8^{0} 33^{\prime} 32,4^{\prime \prime}$ & $114^{0} 31^{\prime} 8,4^{\prime \prime}$ \\
6. & & $8^{0} 26^{\prime} 24^{\prime \prime}$ & $114^{0} 33^{\prime} 36^{\prime \prime}$ \\
7. & & $8^{0} 35^{\prime} 52,8^{\prime \prime}$ & $114^{0} 33^{\prime} 36^{\prime \prime}$ \\
\hline
\end{tabular}

Lanjutan Tabel 4. Koordinat Daerah Potensi Ikan

\begin{tabular}{|c|c|c|c|}
\hline No & Tanggal & Lintang & Bujur \\
\hline 8. & April 2012 & $8^{0} 26^{\prime} 24^{\prime \prime}$ & $114^{0} 35^{\prime} 24^{\prime \prime}$ \\
\hline 9. & & $8^{0} 28^{\prime} 48^{\prime \prime}$ & $114^{0} 35^{\prime} 24^{\prime \prime}$ \\
\hline 10. & & $8^{0} 33^{\prime} 32,4^{\prime \prime}$ & $114^{0} 35^{\prime} 24^{\prime \prime}$ \\
\hline 11. & & $8^{0} 26^{\prime} 24^{\prime \prime}$ & $114^{0} 38^{\prime} 24^{\prime \prime}$ \\
\hline 12. & & $8^{0} 33^{\prime} 32,4^{\prime \prime}$ & $114^{0} 38^{\prime} 24^{\prime \prime}$ \\
\hline 13. & & $8^{0} 26^{\prime} 24^{\prime \prime}$ & $114^{\circ} 40^{\prime} 44,4^{\prime \prime}$ \\
\hline 14. & & $8^{0} 40^{\prime} 48^{\prime \prime}$ & $114^{\circ} 40^{\prime} 44,4^{\prime \prime}$ \\
\hline 15. & & $8^{0} 50^{\prime} 16.8^{\prime \prime}$ & $114^{\circ} 40^{\prime} 44,4^{\prime \prime}$ \\
\hline 16. & & $8^{0} 26^{\prime} 24$ & $114^{\circ} 43^{\prime} 12^{\prime \prime}$ \\
\hline 17. & & $8^{0} 38^{\prime} 24^{\prime \prime}$ & $114^{0} 43^{\prime} 12^{\prime \prime}$ \\
\hline 18. & & $8^{0} 40^{\prime} 48^{\prime \prime}$ & $114^{\circ} 43^{\prime} 12^{\prime \prime}$ \\
\hline 19. & & $8^{0} 26^{\prime} 24^{\prime \prime}$ & $114^{0} 45^{\prime} 39,6^{\prime \prime}$ \\
\hline 20. & & $8^{0} 28^{\prime} 48^{\prime \prime}$ & $114^{0} 45^{\prime} 39,6^{\prime \prime}$ \\
\hline 21. & & $8^{0} 35^{\prime} 52,8^{\prime \prime}$ & $114^{0} 45^{\prime} 39,6^{\prime \prime}$ \\
\hline 22. & & $8^{0} 38^{\prime} 24^{\prime \prime}$ & $114^{0} 45^{\prime} 39,6^{\prime \prime}$ \\
\hline 23. & & $8^{0} 40^{\prime} 48^{\prime \prime}$ & $114^{0} 45^{\prime} 39,6^{\prime \prime}$ \\
\hline 24. & & $8^{0} 45^{\prime} 28,8^{\prime \prime}$ & $114^{0} 45^{\prime} 39,6^{\prime \prime}$ \\
\hline 25. & & $8^{0} 35^{\prime} 52,8^{\prime \prime}$ & $114^{\circ} 48^{\prime} 0^{\prime \prime}$ \\
\hline 26. & & $8^{0} 38^{\prime} 24^{\prime \prime}$ & $114^{\circ} 48^{\prime} 0^{\prime \prime}$ \\
\hline 27. & & $8^{0} 40^{\prime} 48^{\prime \prime}$ & $114^{\circ} 48^{\prime} 0^{\prime \prime}$ \\
\hline 28. & & $8^{\circ} 48^{\prime} 3,6^{\prime \prime}$ & $114^{0} 48^{\prime} 0^{\prime \prime}$ \\
\hline 29. & & $8^{0} 43^{\prime} 8,4^{\prime \prime}$ & $114^{0} 50^{\prime} 24^{\prime \prime}$ \\
\hline 30. & & $8^{0} 48^{\prime} 3,6^{\prime \prime}$ & $114^{0} 50^{\prime} 24^{\prime \prime}$ \\
\hline 31. & & $8^{0} 52^{\prime} 51,6^{\prime \prime}$ & $114^{0} 50^{\prime} 24^{\prime \prime}$ \\
\hline 32. & & $8^{0} 43^{\prime} 4,8^{\prime \prime}$ & $114^{0} 52^{\prime} 48^{\prime \prime}$ \\
\hline 33. & & $8^{0} 50^{\prime} 16,8^{\prime \prime}$ & $114^{0} 52^{\prime} 48^{\prime \prime}$ \\
\hline 34. & & $8^{0} 52^{\prime} 51,6^{\prime \prime}$ & $114^{0} 52^{\prime} 48^{\prime \prime}$ \\
\hline 35. & & $8^{0} 43^{\prime} 4,8^{\prime \prime}$ & $114^{0} 55^{\prime} 8,4^{\prime \prime}$ \\
\hline 36. & & $8^{0} 48^{\prime} 3,6^{\prime \prime}$ & $114^{0} 55^{\prime} 8,4^{\prime \prime}$ \\
\hline 37. & & $8^{0} 50^{\prime} 16,8^{\prime \prime}$ & $114^{0} 55^{\prime} 8,4^{\prime \prime}$ \\
\hline 38. & & $8^{0} 52^{\prime} 51,6^{\prime \prime}$ & $114^{0} 55^{\prime} 8,4^{\prime \prime}$ \\
\hline 39. & & $8^{0} 40^{\prime} 48^{\prime \prime}$ & $114^{0} 2^{\prime} 27,6^{\prime \prime}$ \\
\hline
\end{tabular}




\begin{tabular}{|c|c|c|c|}
\hline 40. & & $8^{0} 45^{\prime} 28,8^{\prime \prime}$ & $114^{0} 2^{\prime} 27,6^{\prime \prime}$ \\
\hline 41. & & $8^{0} 52^{\prime} 51,6$ & $114^{0} 2^{\prime} 27,6^{\prime \prime}$ \\
\hline 42. & & $8^{0} 45^{\prime} 28,8^{\prime \prime}$ & $114^{0} 5^{\prime} 27,6^{\prime \prime}$ \\
\hline 43. & & $8^{0} 52^{\prime} 51,6^{\prime \prime}$ & $114^{0} 5^{\prime} 27,6^{\prime \prime}$ \\
\hline 44. & & $8^{0} 43^{\prime} 4,8^{\prime \prime}$ & $114^{0} 7^{\prime} 15,6^{\prime \prime}$ \\
\hline 45. & & $8^{0} 52^{\prime} 51,6^{\prime \prime}$ & $115^{0} 12^{\prime} 3,6^{\prime \prime}$ \\
\hline 46. & Oktober 2012 & $8^{0} 33^{\prime} 32,4^{\prime \prime}$ & $114^{0} 59^{\prime} 52,8^{\prime \prime}$ \\
\hline 47. & Mei 2013 & $8^{0} 48^{\prime} 3,6^{\prime \prime}$ & $114^{0} 33^{\prime} 36^{\prime \prime}$ \\
\hline 48. & & $8^{0} 52^{\prime} 51,6^{\prime \prime}$ & $114^{0} 33^{\prime} 36^{\prime \prime}$ \\
\hline 49. & & $8^{0} 50^{\prime} 16,8^{\prime \prime}$ & $114^{0} 38^{\prime} 24^{\prime \prime}$ \\
\hline 50. & & $8^{0} 50^{\prime} 16,8^{\prime \prime}$ & $114^{0} 40^{\prime} 44,4^{\prime \prime}$ \\
\hline 51. & & $8^{0} 52^{\prime} 51,6^{\prime \prime}$ & $114^{0} 40^{\prime} 44,4^{\prime \prime}$ \\
\hline 52. & & $8^{0} 50^{\prime} 16,8^{\prime \prime}$ & $114^{0} 43^{\prime} 12^{\prime \prime}$ \\
\hline 53. & & $8^{0} 48^{\prime} 3,6^{\prime \prime}$ & $114^{0} 45^{\prime} 39,6^{\prime \prime}$ \\
\hline 54. & & $8^{0} 50^{\prime} 16,8^{\prime \prime}$ & $114^{0} 45^{\prime} 39,6^{\prime \prime}$ \\
\hline 55. & & $8^{0} 43^{\prime} 4,8^{\prime \prime}$ & $114^{0} 50^{\prime} 16,8^{\prime \prime}$ \\
\hline 56. & & $8^{0} 48^{\prime} 3,6^{\prime \prime}$ & $114^{0} 55^{\prime} 8,4^{\prime \prime}$ \\
\hline 57. & & $8^{0} 48^{\prime} 3,6^{\prime \prime}$ & $114^{0} 59^{\prime} 52,8^{\prime \prime}$ \\
\hline 58. & & $8^{0} 38^{\prime} 24^{\prime \prime}$ & $115^{0} 2^{\prime} 27,6^{\prime \prime}$ \\
\hline 59. & & $8^{0} 40^{\prime} 48^{\prime \prime}$ & $115^{0} 2^{\prime} 27,6^{\prime \prime}$ \\
\hline 60. & & $8^{0} 40^{\prime} 48^{\prime \prime}$ & $115^{0} 5^{\prime} 27,6^{\prime \prime}$ \\
\hline \multicolumn{4}{|c|}{ Lanjutan Tabel 4. Koordinat Daerah Potensi Ikan } \\
\hline No & Tanggal & Lintang & Bujur \\
\hline 61. & & $8^{0} 43^{\prime} 4,8^{\prime \prime}$ & $115^{0} 5^{\prime} 27,6^{\prime \prime}$ \\
\hline 62. & & $8^{0} 45^{\prime} 28,8^{\prime \prime}$ & $115^{0} 5^{\prime} 27,6^{\prime \prime}$ \\
\hline 63. & & $8^{0} 52^{\prime} 51,6^{\prime \prime}$ & $115^{0} 5^{\prime} 27,6^{\prime \prime}$ \\
\hline 64. & & $8^{0} 43^{\prime} 4,8^{\prime \prime}$ & $115^{0} 7^{\prime} 15,6^{\prime \prime}$ \\
\hline 65. & & $8^{0} 45^{\prime} 28,8^{\prime \prime}$ & $115^{0} 7^{\prime} 15,6^{\prime \prime}$ \\
\hline 66. & & $8^{0} 52^{\prime} 52,6^{\prime \prime}$ & $115^{0} 7^{\prime} 15,6^{\prime \prime}$ \\
\hline 67. & & $8^{0} 52^{\prime} 52,6^{\prime \prime}$ & $115^{0} 9^{\prime} 32,4^{\prime \prime}$ \\
\hline 68. & & $8^{0} 52^{\prime} 52,6^{\prime \prime}$ & $115^{0} 12^{\prime} 3,6^{\prime \prime}$ \\
\hline
\end{tabular}

4. Hasil Korelasi Data Citra dengan Data Lapangan

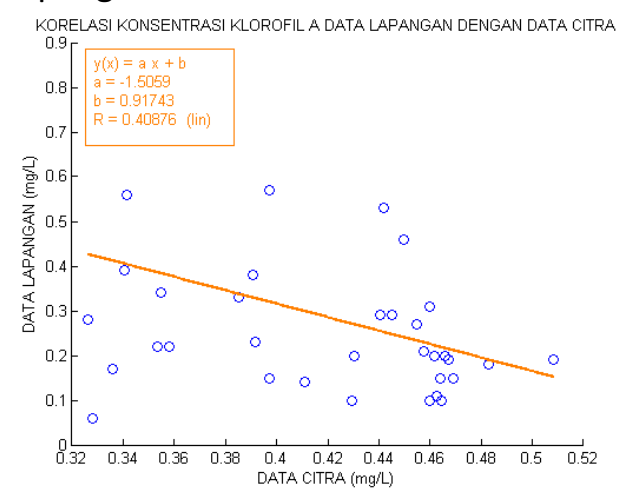

Gambar 12. Grafik Korelasi Klorofil a Data Lapangan dengan Data Citra

Berdasarkan Gambar 12 didapatkan nilai korelasi konsentrasi klorofil-a sebesar 0,40876 dan regresi sederhana mendapatkan persamaan $Y=-1,5059 \mathrm{X}+$ 0,91743 . Berdasarkan hasil tersebut maka dapat disimpulkan bahwa nilai konsentrasi klorofil-a hasil pengolahan memiliki pengaruh yang cukup baik terhadap data lapangan yaitu sebesar 40,876\% (Syarifruddin 2014 dalam Trijayanto 2015). Hal tersebut terjadi akibat persebaran titik-titik sampel yang cenderung menyebar. Menurut Ramansyah, (2010) dalam Semedi dan Safitri (2015) hasil analisa citra satelit bisa memberikan kisaran sebaran klorofil yang berbeda dengan lokasi sebenarnya karena tidak semua parameter kelautan dan wilayah pesisir dapat dideteksi dengan penginderaan jauh.

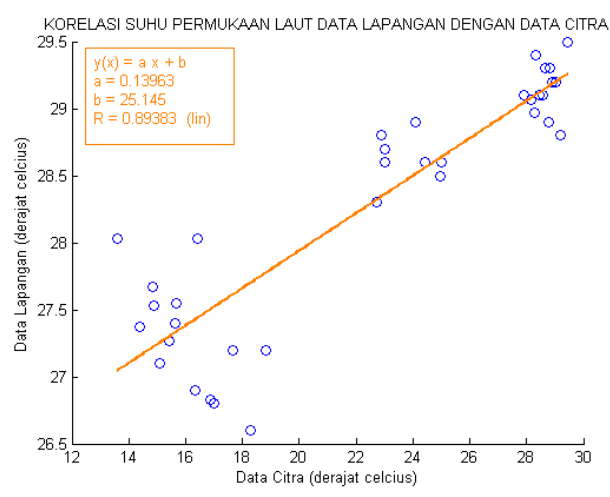

\section{Gambar 13. Grafik Korelasi SPL Data Lapangan dengan Data Citra}

Berdasarkan Gambar 13 didapatkan nilai korelasi SPL sebesar 0,89383 dan regresi linier sederhana mendapatkan persamaan $\mathrm{Y}=$ $0,13363 X+25,145$. Berdasarkan hasil tersebut maka dapat disimpulkan bahwa nilai SPL hasil pengolahan memiliki pengaruh yang kuat terhadap data lapangan yaitu sebesar $89,383 \%$ (Syarifruddin 2014 dalam Trijayanto 2015).

5. Analisis Perubahan Daerah Potensi Ikan Berdasarkan hasil pemetaan daerah potensi ikan didapatkan perubahan baik berupa perubahan letak maupun jumlah daerah potensinya. Pada bulan April 2012 memiliki 45 daerah potensi ikan dengan persebaran yang cukup merata di Selat Bali. Hal tersebut terjadi karena persebaran klorofil a dan SPLyang merata diikuti dengan front thermal yang terjadi hampir di seluruh wilayah selat Bali. Pada bulan Oktober 2012 memiliki 1 daerah potensi ikan. Hal tersebut terjadi karena persebaran klorofil a yang merata namun SPL yang cenderung rendah dan tidak sesuai dengan suhu optimum fitoplankton. Pada bulan Mei 2013 memiliki 22 daerah potensi ikan dengan persebaran klorofil a yang merata 
namun SPL cenderung tinggi di selat Bali bagian selatan yang berhadapan langsung dengan Samudra Hindia.

Pada bulan April 2012 dan Mei 2013 memiliki jumlah daerah potensi ikan yang lebih banyak daripada bulan Oktober 2010. Hal ini disebabkan karena pada musim Timur terjadi fenomena Upwelling di Samudera Hindia. Pada Musim timur juga massa air bergerak dari Selatan Selat Bali menuju Utara Selat. Sehingga pada musim Timur Perairan Selat Bali memiliki tingkat kesuburan yang lebih tinggi dibandingkan pada Musim barat, dikarenakan massa air hasil upwelling dari Samudera Hindia yang memiliki unsur hara yang lebih banyak memasuki Perairan Selat Bali (Safitri, Hariadi dan Sugianto 2014).

Dari ketiga keadaan tersebut dapat dianalisis bahwa perubahan daerah potensi ikan lebih dipengaruhi oleh perubahan SPL. Hal tersebut sesuai dengan pernyataan Nontji (1987) dalam Basuma (2009) yang menyatakan bahwa suhu merupakan parameter oseanografi yang mempunyai pengaruh sangat dominan khususnya terhadap kehidupan ikan dan sumber daya hayati laut. Sebagian besar biota laut bersifat poikilometrik (suhu tubuh dipengaruhi lingkungan) sehingga suhu merupakan salah satu faktor yang sangat penting dalam mengatur proses kehidupan dan penyebaran organisme (Nybakken 1992 dalam Basuma 2009).

\section{KESIMPULAN}

Berdasarkan hasil dan pembahasan tersebut dapat ditarik kesimpulan yaitu:

a. Berdasarkan pemetaan daerah potensi ikan didapatkan perubahan daerah potensi ikan dengan jumlah daerah potensi ikan tiap bulannya sebagai berikut 45 daerah pada bulan April 2012, 1 daerah pada bulan Oktober 2012 dan 22 daerah pada bulan Mei 2013.

b. Data klorofil a citra dengan data lapangan memiliki korelasi cukup kuat dengan nilai korelasi sebsar 0,40876 dengan persamaan Regresi Linier Sederhana $Y=-1,5059 X+$ 0,91743 , sedangkan data SPL citra dengan data lapangan memiliki korelasi yang kuat dengan nilai korelasi sebesar 0,89383 dengan persamaan Regresi Linier Sederhana $\mathrm{Y}=$ $0,13363 X+25,145$.

c. Perubahan daerah potensi ikan lebih dipengaruhi oleh perubahan SPL dibandingkan klorofil-a karena suhu merupakan parameter oseanografi yang mempunyai pengaruh sangat dominan khususnya terhadap kehidupan ikan dan sumber daya hayati laut.

a. Diperlukan pemilihan waktu (tanggal) dari citra yang tepat untuk meminimalisir kesalahan akibat awan atau efek atmosfer.

b. Untuk mendapatkan daerah potensi ikan yang lebih akurat disarankan menggunakan algoritma klorofil a dan SPL yang sesuai dengan area studi serta disarankan untuk menambahkan parameter lainnya seperti parameter arus dan tinggi muka air laut menggunakan data dari satelit altimetri.

\section{UCAPAN TERIMA KASIH}

Kami sampaikan terima kasih kepada kepada Departemen Geomatika ITS yang telah memberikan dukungan administrasi dan pendanaan sehingga penelitian ini dapat berjalan dengan baik dan lancar.

\section{DAFTAR PUSTAKA}

Arafah, F., Sukojo, B. M., \& Jaelani, L. M. (2015). Modifikasi Algortma AVHRR Untuk Estimasi Suhu Permukaan Laut (SPL) Citra Satelit Terra Modis. 1-7.

Arianto, B. Y., Subiyanto, S., \& hani'ah. (2014). ANALISIS HUBUNGAN PRODUKTIVITAS IKAN LEMURU DENGAN SUHU PERMUKAAN LAUT DAN KLOROFIL-A MENGGUNAKAN CITRA SATELIT AQUA MODIS (Studi Kasus : Selat Bali). Jurnal Geodesi UNDIP Volume 3, Nomor 4, Tahun 2014, (ISSN : 2337-845X), 158-168.

Basuma, T. (2009). Penentuan Daerah Penangkapan Ikan Tongkol Berdasarkan Pendekatan Suhu Permukaan Laut dan Hasil Tangkapan di Perairan Binuangeun, Banten. Bogor: Departemen Pemanfaatan Sumberdaya Perikanan-FPIK IPB.

Effendi, H. (2003). Telaah Kualitas Air: Bagi Pengelolaan Sumberdaya dan Lingkungan Perairan. Bogor: Jurusan Manajemen Sumberdaya Perairan Fakultas Perikanan dan IImu Kelautan Institut Pertanian Bogor. 
Habibie, M. N., \& Nuraini, T. A. (2014). Karakteristik dan Tren Perubahan Suhu Permukaan Laut di Indonesia Periode 1982-2009. Jurnal Meteorologi dan Geofisika Volume 15 Nomor 1, 37-49.

Indrayani, Mallawa, A., \& Zainuddin, M. (2012). Penentuan Karakteristik Habitat Daerah Potensi Ikan Pelagis Kecil Dengan Pendekatan Spasial Di Perairan Sinjai. Makassar: Fakultas Ilmu Kelautan dan Perikanan, Universitas Hasanuddin.

Jatisworo, D., \& Murdimanto, A. (2013). Identifikasi Thermal Front Di Selat Makassar Dan Laut Banda.

Pratama, A. F. (2014, Agustus 14). Tribun Bisnis. Dipetik January 3, 2016, dari http://www.tribunnews.com/bisnis/2014/08/ 14/potensi-kelautan-indonesia-mencapai171-miliar-dollar-as

Safitri, W., Hariadi, \& Sugianto, D. N. (2014). Analisa Hubungan Nitrat Terhadap Distribusi Klorofila di Perairan Selatan Selat Bali Pada Musim Timur. Jurnal Oseanografi Volume 3 Nomor 1, 7-15.

Semedi, B., \& Safitri, N. M. (2015). Estimasi Distribusi Klorofil-a di Perairan Selat Madura Menggunakan Data Citra Satelit Modis dan Pengukuran In Situ Pada Musim Timur. Research Journal of Life Science Volume 02 No. 01, 40-49.

Septiawan, A. W. (2006). Pemetaan Persebaran Klorofil Wilayah Perairan Selat Bali Menggunakan Teknologi Penginderaan Jauh. Surabaya: Teknik Geodesi FTSP-ITS.

Suwargana, N., \& Arief, M. (2004). Penentuan Suhu Permukaan Laut dan Konsentrasi Klorofil Untuk Pengembangan Model Prediksi Fishing Ground Dengan Menggunakan Data Modis. Jurnal Penginderaan Jauh dan Pengolahan Data Citra Digital Vol. 1 No. 1, 1-13.

Trijayanto, D. P. (2015). Analisa Persebaran Potensi Ikan Dengan Menggunakan Data Modis, VIIRS dan Insitu (Studi Kasus: Selat Madura). Surabaya: Jurusan Teknik Geomatika-FTSP ITS. 